Volume 1 Issue 1, January-June 2020: PP: 27-38

Faculty of Law, Universitas Lampung, Bandar Lampung, Indonesia.

http://jurnal.fh.unila.ac.id/index.php/constitutionale

P-ISSN: 2723-2492

E-ISSN: $2745-9322$

\title{
Rekrutmen Hakim Pengadilan Tingkat Pertama Dalam Perspektif Ketatanegaraan di Indonesia
}

\section{Recruitment of First Level Court Judges in a State Administration Perspective in Indonesia}

\author{
Hendi Gusta Rianda \\ hendigustarianda@gmail.com
}

Lembaga Bantuan Hukum Bandar Lampung

Submitted: Mar 3, 2020; Reviewed: Mar 24, 2020; Accepted: Apr 14, 2020

\begin{tabular}{|c|c|}
\hline Info Artikel & Abstrak \\
\hline $\begin{array}{l}\text { Kata Kunci: Hakim; Pengadilan; Mahkamah } \\
\text { Konstitusi. } \\
\text { Keywords: Judges; Courts; Constitutional Court. } \\
\text { DOI: } \\
\text { https://doi.org/10.25041/constitutionale.v1i1.2014 }\end{array}$ & $\begin{array}{l}\text { Pasang surut dan konfigurasi politik } \\
\text { yang terjadi di Indonesia sejak orde } \\
\text { lama, orde baru hingga reformasi } \\
\text { mempengaruhi sistem kekuasaan } \\
\text { kehakiman di Indonesia hingga } \\
\text { berdampak pada rekruitmen hakim } \\
\text { pengadilan tingkat pertama. } \\
\text { Penelitian ini bertujuan mengetahui } \\
\text { rekruitmen hakim pengadilan } \\
\text { tingkat pertama sejak orde lama } \\
\text { hingga terbitnya Putusan } \\
\text { Mahkamah Konstitusi Nomor } \\
\text { 43/PUU-XIII/2015. Jenis penelitian } \\
\text { ini adalah penelitian yuridis } \\
\text { normatif dengan cara melakukan } \\
\text { pengkajian pendekatan historical } \\
\text { approach dan comparative } \\
\text { approach. Hasil penelitian } \\
\text { menunjukkan bahwa pasca putusan } \\
\text { Mahkamah Konstitusi Nomor } \\
\text { 43/PUU XIII/2015, rekruitmen } \\
\text { hakim pengadilan tingkat pertama }\end{array}$ \\
\hline
\end{tabular}


yang dilakukan Mahkamah Agung pada tahun 2017 masih dengan pola rekrutmen yang sama dengan sebelumnya yaitu aparatur sipil negara.

Abstract
The ups and downs and political
configurations that have occurred in
Indonesia since the old order, the
new order until the reformation
have affected the judicial power
system in Indonesia and thus have
an impact on the recruitment of
first-level court judges. This study
aims to determine the recruitment of
first-level court judges since the old
order until the issuance of the
Constitutional Court Decision
Number 43/PUU-XIII/2015. This
type of research is a normative
juridical research by assessing the
historical approach and the
comparative approach. The results
showed that after the Constitutional
Court decision Number 43 / PUU
XIII / 2015, the recruitment of first-
level court judges by the Supreme
Court in 2017 was still with the
same recruitment pattern as before,
namely state civil servants.

\section{A. Pendahuluan}

Negara hukum (rechtsstaat atau the rule of law) merupakan konsep negara ideal pendiri bangsa yang membahas dan merumuskan Undang-Undang Dasar Negara Republik Indonesia Tahun 1945 sebagaimana kemudian dituangkan dalam penjelasan Undang-Undang Dasar Negara Republik Indonesia Tahun 1945 sebelum perubahan. ${ }^{1}$ Indonesia dalam UUD 1945 merupakan negara berdasarkan atas hukum (rechstaat) ${ }^{2}$ yang dalam perkembangan

\footnotetext{
1 Jimly Asshidiqie, Implikasi Perubahan UUD 1945 Terhadap Pembangunan Hukum Nasional, (Jakarta: Mahkamah Konstitusi, 2006), hlm. 21. Sebagaimana sebuah negara hukum, maka hukum harus dipahami dan dikembangkan sebagai satu kesatuan sistem. Sebagai sebuah sistem, hukum terdiri dari elemen-elemen (1) kelembagaan (Institusional); (2) kaedah aturan (instrumental); (3) perilaku para subyek hukum yang menyandang hak dan kewajiban yang ditentukan oleh norma aturan itu (elemen subyektif dan kultural). Ketiga elemen sistem hukum tersebut mencakup (a) kegiatan pembuatan hukum (law making), (b) kegiatan pelaksanaan hukum dan penerapan hukum (law administrating), dan (c) kegiatan peradilan atas pelanggaran hukum (law adjudicating) atau yang biasa disebut penegakan hukum dalam arti sempit (law enforcement).

2 Jeffry Alexander Ch. Likadja, "Memaknai 'Hukum Negara (Law Through State)' Dalam Bingkai 'Negara Hukum (Rechtstaat)," Hasanuddin Law Review 1, no. 1 (2015): 75-86.
} 
ketatanegaraannya saat ini beralih menjadi negara hukum konstitusional sehingga segala kekuasaan dari alat-alat pemerintahannya didasarkan pada hukum. ${ }^{3}$ Hukum dasar (konstitusi) merupakan suatu langkah awal pengaturan ketatanegaraan sumber hukum utama. Konstitusi memuat hal-hal pokok yang menjadi dasar menata sebuah negara karena pada dasarnya mengatur mengenai ketatanegaraan dan kehidupan bernegara. ${ }^{4}$ Konstitusi mempunyai fungsi membatasi kekuasaan pemerintah karena kekuasaan itu sendiri pada intinya memang perlu diatur dan dibatasi sebagaimana mestinya. ${ }^{5}$ Menurut Montesquieu, bahwa kekuasaan harus dipisahkan menjadi tiga organ kekuasaan ${ }^{6}$ yang dalam pandangannnya harus dibedakan dan dipisahkan secara struktural dalam organ-organ yang tidak saling mencampuri urusan masingmasing. ${ }^{7}$ Organ-organ tersebut yakni eksekutif, legislatif, dan yudikatif. Oleh sebab itu, dalam menentukan konstitusionalisme suatu tindakan atau suatu pelaksanaan kekuasaan, ajaran konstitusionalisme mempersyaratkan setidaknya-tidaknya: ${ }^{8}$

1. bahwa pelaksanaan kekuasaan harus dalam batas-batas ketentuan undang-undang terhadap mereka yang diberi kekuasaan itu dan bahwa mereka yang melaksakan kekuasaan itu bertanggung jawab kepada hukum;

2. bahwa pelaksanaan kekuasaan harus sesuai dengan gagasan penghormatan individu dan hak-hak perorangan warga negara $;^{9}$

3. bahwa kekuasaan yang diberikan kepada lembaga-lembaga dalam suatu negara (legislatif, eksekutif, maupun yudisial) harus disebar dengan tepat di antara berbagai macam lembaga negara tersebut guna menghindari terjadinya penyalahgunaan kekuasaan; dan

4. bahwa pemerintah, dalam merumuskan kebijakan tersebut, bertanggung jawab kepada pemilih yang memberi mereka kepercayaan untuk memegang kekuasaan itu.

Sejak berlakunya UUD 1945 (tanggal 18 Agustus 1945) hingga kini, tiga undang-undang pokok yang mengatur kekuasaan kehakiman yakni Undang-Undang Nomor 19 Tahun 1948 tentang Susunan Dan Kekuasaan Badan-Badan Kehakiman Dan Kejaksaan, Undang-Undang Nomor 19 Tahun 1964 tentang Ketentuan-Ketentuan Pokok Kekuasaan Kehakiman dan Undang-Undang Nomor 14 Tahun 1970 tentang Ketentuan-Ketentuan Pokok Kekuasaan Kehakiman, Undang-Undang Republik Indonesia Nomor 35 Tahun 1999 tentang Perubahan Atas Undang-Undang Nomor 14 Tahun 1970 tentang Ketentuan-Ketentuan Pokok Kekuasaan Kehakiman, Undang-Undang Nomor 4 Tahun 2004 tentang Kekuasaan Kehakiman serta Undang-Undang Nomor 48 Tahun 2009 tentang Kekuasaan Kehakiman. Sebelum berlakunya UU Nomor 19 Tahun 1948 sepanjang menyangkut peraturan-peraturan dan badan-badan atau institusi yang berkaitan dengan kekuasaan kehakiman berlaku peraturan-peraturan dan badanbadan sebelum kemerdekaan (masa Jepang dan Belanda). Pemberlakuan semacam itu

\footnotetext{
${ }^{3}$ Rudy, Konstitusi dan Konstitusionalisme: Buku I Dasar dan Teori, (Bandar Lampung: PKKPUU FH UNILA, 2013), hlm. 11. Negara hukum konstitusional bermakna bahwa segala tindakan negara harus didasarkan pada konstitusi dan hukum yang berintikan pada pengayoman kepada warga negara yang mempunyai tujuan akhir kepada kesejahteraan.

${ }^{4}$ Zulkarnain Ridlwan, "Negara Hukum Indonesia Kebalikan Nachtwachterstaat," FIAT JUSTISIA:Jurnal Ilmu Hukum 5, no. 2 (2014): 141-52, https://doi.org/10.25041/fiatjustisia.v5no2.56.

${ }_{5}^{5}$ Jimly Asshdiqie, Pengantar Ilmu Hukum Tata Negara Jilid I, (Jakarta: Sekretariat Jenderal dan Kepaniteraan MK RI, 2006), hlm. 116. Oleh karena itu, pembatasan kekuasaan pada umumnya dianggap merupakan corak umum materi konstitusi. Persoalan yang dianggap terpenting dalam setiap konstitusi adalah pengaturan mengenai pengawasan atau pembatasan terhadap kekuasaan pemerintahan.

${ }^{6}$ Bustamin Bustamin and Rony Jaya, "Urgensi Checks And Balances Ketatanegaraan Indonesia Dan Islam," JURIS (Jurnal Ilmiah Syariah) 18, no. 2 (2019): 221-32, https://doi.org/10.31958/juris.v18i2.1740.

${ }^{7}$ Jimly Asshdiqie, Pengantar Ilmu Hukum Tata Negara, (Jakarta: Sinar Grafika, 2009) hlm. 285.

${ }^{8}$ Gede Dewa Palguna, Pengaduan Konstitusional, (Jakarta: Sinar Grafika, 2013),hlm. 27.

9 M. Muslih, "Negara Rukum Indonesia Dalam Perspektif Teori Hukum Gustav Radbruch (Tiga Nilai Dasar Hukum)," Legalitas Edisi Juni 2013 4, no. 1 (2013): 142.
} 
didasarkan pada ketentuan Pasal II Aturan Peralihan UUD 1945 pada intinya mengatakan bahwa segala badan negara dan peraturan yang ada masih terus berlaku selama belum diadakan yang baru menurut Undang-undang Dasar. Substansi yang terkandung dalam peraturan tersebut, kekuasaan kehakiman adalah kekuasaan negara yang merdeka untuk menyelenggarakan peradilan guna menegakkan hukum dan keadilan berdasarkan Pancasila dan Undang-Undang Dasar Negara Republik Indonesia Tahun 1945 demi terselenggaranya Negara Hukum Republik Indonesia. ${ }^{10}$ Begitu pula dengan mekanisme rekrutmen calon hakim pada pengadilan tingkat pertama yang selalu berubah dengan mengikuti perkembangan peraturan perundang-undangan yang berlaku semenjak orde lama hingga reformasi yang menghasilkan amandemen Undang-Undang Dasar 1945.

Setelah amandemen Undang-Undang Dasar 1945, perubahan tersebut berpengaruh cukup besar pada kekuasaan kehakiman di Indonesia. ${ }^{11}$ Hasil amandemen ketiga UUD 1945 menghasilkan Mahkamah Konstitusi sebagai penjaga Konstitusi (The Guard of Constitution $)^{12}$ sebagai lembaga kekuasaan kehakiman tertinggi selain Mahkamah Agung serta Komisi Yudisial. Secara konstitusional, Pasal 24B ayat (1) perubahan ketiga UUD 1945 meletakkan Komisi Yudisial sebagai lembaga negara yang bersifat mandiri yang berwenang mengusulkan pengangkatan hakim agung dan mempunyai wewenang lain dalam rangka menjaga dan menegakkan kehormatan, keluhuran martabat, serta perilaku hakim. Sebagai negara hukum, masalah kehormatan, keluhuran martabat, serta perilaku hakim merupakan hal yang sangat strategis untuk mendukung upaya mewujudkan peradilan yang bersih, ${ }^{13}$ hal itu didasari pemikiran bahwa para hakim merupakan figur yang sangat menentukan dalam menegakkan hukum dan keadilan. Dengan fungsi sepenting itu, maka hakim diharapkan dapat menjadi benteng terakhir (the last resort) bagi para pencari keadilan (justiciable). ${ }^{14}$ Meskipun konstitusi hanya memberikan kewenangan terhadap Komisi Yudisial untuk melakukan seleksi hakim agung saja, namun berdasarkan ketentuan tiga undang-undangbidang peradilan tahun 2009, Komisi Yudisial juga diberikan wewenang yang lebih luas lagi, yaitu Komisi Yudisial bersama Mahkamah Agung memiliki kewenangan untuk melakukan seleksi pengangkatan hakim pada Pengadilan Negeri, Pengadilan Agama, dan Pengadilan Tata Usaha Negara.

Mengenai rekruitmen hakim, meskipun konstitusi hanya memberikan kewenangan terhadap Komisi Yudisial untuk melakukan seleksi hakim agung saja, namun berdasarkan ketentuan tiga undang-undang peradilan tahun 2009, Komisi Yudisial juga diberikan wewenang yang lebih luas lagi yakni Komisi Yudisial bersama Mahkamah Agung memiliki

\footnotetext{
${ }^{10}$ Bambang Sutiyoso, "Mencari Format Ideal," Jurnal Hukum IUS QUIA IUSTUM 17, no. 2 (2010): 217, http://www.sunanampel.ac.id/publicactivity/.

${ }^{11}$ W. Dramanda, "Menggagas Penerapan Judicial Restraint Di Mahkamah Konstitusi," Jurnal Konstitusi 11, no. 4 (2014): 617-31.

${ }^{12}$ Jimly Asshidiqie, Perkembangan dan Konsolidasi Lembaga Negara Pasca Reformasi, (Jakarta: Sinar Grafika, 2012), hlm. 131. Dalam menjalankan fungsinya sebagai pengawal konstitusi, Mahkamah Konstitusi Republik Indonesia dilengkapi dengan lima kewenangan atau sering disebut empat kewenangan dan satu kewajiban, yaitu a) menguji undang-undang terhadap Undang-Undang Dasar; b) memutus sengketa kewenangan lembaga negara yang kewenangannya diberikan oleh Undang-Undang Dasar; c) memutus pembubaran partai politik; d) memutus perselisihan tentang hasil pemilihan umum; e)memutus pendapat DPR bahwa Presiden dan/atau Wakil Presiden telah melakukan pelanggaran hukum berupa pengkhianatan terhadap negara, korupsi, penyuapan, tindak pidana berat lainnya atau perbuatan tercela;

${ }^{13}$ Meylin Sihaloho, "Seleksi Pengangkatan Hakim Dalam Sistem Peradilan Indonesia: Kajian Putusan Mahkamah Konstitusi Nomor 43/Puu-Xii/2015," Jurnal Wawasan Yuridika 33, no. 2 (2016): 204-18, https://doi.org/10.25072/jwy.v33i2.103.

${ }^{14}$ Taufiqurrohman Syahuri, Pembaharuan Sistem Hakim Sebagai Pondasi Mewujudkan Peradilan Bersih (makalah), 2013, Komisi Yudisial: Jakarta, hlm. 2. Perluasan kewenangan Komisi Yudisial untuk melakukan seleksi dan pengusulan hakim pada dasarnya merupakan penjabaran kewenangan Komisi Yudisial dalam konstitusi yang kemudian diatur dalam undangundang bidang peradilan tahun 2009 untuk menegakkan kehormatan, keluhuran martabat, serta perilaku hakim. Sehingga dengan adanya perluasanwewenang Komisi Yudisial tersebut, maka kemudian dirumuskan suatu peraturan bersama antara Mahkamah Agung dan Komisi Yudisial tentang tata cara seleksi hakim.
} 
kewenangan untuk melakukan seleksi pengangkatan hakim pada Pengadilan Negeri, Pengadilan Agama, dan Pengadilan Tata Usaha Negara.

Pasca dikeluarkannya Putusan Mahkamah Konstitusi Nomor 43/PUU-XIII/2015 membatalkan kewenangan komisi yudisial dalam seleksi hakim tingkat pertama di tiga lingkungan peradilan. Maka, kewenangan seleksi calon hakim tetap menjadi wewenang tunggal Mahkamah Agung. Adapun amar putusan mengabulkan seluruh permohonan pemohon yaitu:

1) Pasal 14A ayat (2) dan (3) sepanjang frasa "bersama" serta "dan Komisi Yudisial" Undang-Undang Nomor 49 Tahun 2009 Tentang Peradilan Umum bertentangan dengan UUD 1945 dan tidak mempunyai kekuatan hukum mengikat;

2) Pasal 13A ayat (2) dan (3) ) sepanjang frasa "bersama" serta "dan Komisi Yudisial" Undang-Undang Nomor 50 Tahun 2009 Tentang Peradilan Agama bertentangan dengan UUD 1945 dan tidak mempunyai kekuatan hukum mengikat;

3) Pasal 14A ayat (2) dan (3) sepanjang frasa "bersama" serta "dan Komisi Yudisial" Undang-Undang Nomor 51 Tahun 2009 Tentang Peradilan Tata Usaha Negara bertentangan dengan UUD 1945 dan tidak mempunyai kekuatan hukum mengikat;

Keberlakuan putusan tersebut menarik dikaji tentang keberadaan Komisi Yudisial sebagai lembaga kontrol (institutional watchdog) dalam lingkup kekuasaan kehakiman yang diberikan keluasan wewenang terkait pengangkatan hakim peradilan tingkat pertama, dimana satu sisi secara atributif konstitusi hanya memberikan wewenang Komisi Yudisial untuk mengangkat hakim agung maupun hakim ad hoc dalam lingkungan Mahkamah Agung serta wewenang lainnya dalam rangka menjaga dan menegakkan kehormatan, keluhuran martabat, serta perilaku hakim. Berdasarkan penjelasan latar belakang di atas, permasalahan yang akan dikaji dalam penelitian ini bagaimana mekanisme rekruitmen calon hakim pengadilan tingkat pertama sejak orde lama sampai terbitnya Putusan Mahkamah Konstitusi Nomor 43/PUU$\mathrm{XIII} / 2015$.

\section{B. Pembahasan}

\section{Rekrutmen Hakim Pengadilan Tingkat Pertama Era Orde Lama}

Memperhatikan pengaturan kekuasaan kehakiman sebagaimana tercantum dalam Pasal 24 dan 25 Undang-Undang Dasar 1945, sebagai bangsa yang baru merdeka itu telah mengenal konsep kekuasaan kehakiman yang bebas dan merdeka, yaitu dengan mengamanatkan agar diatur lebih lanjut dalam suatu undang-undang. Untuk menindaklanjuti ketentuan tersebut maka diterbitkan Peraturan Pemerintah Nomor 2 Tahun 1945 tentang Badan-Badan dan Peraturan Pemerintah Dulu yang diterbitkan tanggal 10 Oktober 1945. ${ }^{15}$ Namun dalam perjalanannya di era kepemimpinan Presiden Soekarno, lembaga peradilan maupun hakim itu sendiri tidak terlepas dari intervensi pemerintah dalam menjalankan independensi lembaga peradilan maupun dalam hal rekruitmen hakim. Ketika berada dalam sistem politik demokratis pada periode awal kemerdekaan Indonesia, yang sering disebut periode demokrasi

\footnotetext{
${ }^{15} \mathrm{Hal}$ ini diatur sebagaimana tertuang dalam Pasal II aturan Peralihan Undang-Undang Dasar 1945.Sehingga segala hal yang mengatur mengenai susunan pengadilan masih berlakunya peraturan mengenai kekuasaan kehakiman dalam peraturan pada masa Hindia Belanda sesudah diubah dengan peraturan-peraturan Jepang. Lihat Adies Kadier, Menyelamatkan Wakil Tuhan (Memperkuat Peran dan Kedudukan Hakim), (Jakarta: Merdeka Book, 2018) hlm. 62.
} 
parlementer atau demokrasi liberal, independensi pengadilan relatif terjaga dari pengaruh cabang kekuasaan lain.

Menurut Daniel Lev, selama periode itu, lembaga pengadilan bekerja sangat bagus, meskipun dengan dukungan fasilitas seadanya dan menghadapi banyak hambatan. ${ }^{16}$ Tergerusnya independensi kekuasaan kehakiman dimulai ketika Presiden Soekarno mengeluarkan Dekrit Presiden 5 Juli 1959 yang menjadi dasar atas pembubaran Dewan Konstituante dan berlakunya kembali UUD 1945. Pasca dekrit itu, kekuasaan mengalami personalisasi hampir sepenuhnya berada dalam genggaman Presiden Soekarno yang disebut periode demokrasi terpimpin(Guided Democracy). ${ }^{17}$ Sementara itu dalam hal penempatan posisi dan kedudukan kekuasaan kehakiman pada era Orde Lama tidak merdeka dan cenderung di bawah kekuasaan eksekutif karena Presiden Soekarno menjadikan kekuasaan kehakiman dan peradilan sebagai alat revolusi dalam membangun kemerdekaan Indonesia seutuhnya. Kemudian setelah kembali berlakunya Undang-Undang Dasar 1945 dengan diterbitkannya Dekrit Presiden 5 Juli 1959 juga melahirkan produk hukum di bidang kekuasaan kehakiman dengan diterbitkannnya Undang-Undang Nomor 19 Tahun 1964 tentang Ketentuan-Ketentuan Pokok Kekuasaan Kehakiman dan Undang-Undang Nomor 13 Tahun 1965 tentang Pengaadilan dalam Lingkungan Peradilan Umum dan Mahkamah Agung. Esensi dari dua produk undang-undang yang ditebitkan tersebut adalah sebagai alat kekuasaan revolusi yang dapat dikatakan menyimpang terhadap makna Pasal 24 dan 25 Undang-Undang Dasar 1945 (sebelum amandemen. Dalam hal rekruitmen hakim pada pengadilan tingkat pertama atau pengadilan negeri mekanisme yang dilakukan adalah kewenangan dari kementerian kehakiman.Apabila ditinjau dari sudut pandang kelembagaan negara, proses seleksi hakim pada saat itu mengikutsertakan lembaga eksekutif. Hal ini menurut penulis justru menimbulkan conflict of intrest diantara kedua lembaga tersebut, terlebih demokrasi terpimpin yang dilaksanakan saat itu oleh Presiden Soekarno membuat kurangnya mekanisme saling mengawasi dan berimbang (cheks and balances) diantara lembaga kekuasaan negara.

\section{Rekruitmen Hakim Pengadilan Tingkat Pertama Era Orde Baru}

Demokrasi Pancasila zaman orde baru secara garis besar menawarkan tiga komponen demokrasi. ${ }^{18}$ Pertama, demokrasi dalam bidang politik pada hakikatnya adalah menegakkan kembali asas-asas negara hukum dan kepastian hukum. Kedua, demokrasi dalam bidang ekonomi pada hakikatnya adalah kehidupan yang layak bagi semua warga negara. Ketiga, demokrasi dalam bidang hukum pada hakikatnya bahwa pengakuan dan perlindungan HAM, peradilan yang bebas yang tidak memihak. ${ }^{19}$

\footnotetext{
${ }^{16}$ Daniel Lev, Kata Pengantar dalam Sebastian Pompe, Runtuhnya Institusi Mahkamah Agung, terjemahan Noor Cholis (Jakarta: LeIP, 2012), hlm. 11. Sebagaimana dikutip kembali oleh Komisi Yudisial, Problematika Hakim dalam Ranah Hukum, Pengadilan dan Masyarakat di Indonesia: Studi Sosio-Legal, (Jakarta: Pusat Analisis dan Informasi Komisi Yudisial, 2017), hlm. 31.

${ }^{17}$ Ibid, hlm 33.

18 Aulia Rosa Nasution, "Urgensi Pendidikan Kewarganegaraan Sebagai Pendidikan Karakter Bangsa Indonesia Melalui Demokrasi, HAM Dan Masyarakat Madani," JUPIIS: JURNAL PENDIDIKAN ILMU-ILMU SOSIAL 8, no. 2 (2016): 20112, https://doi.org/10.24114/jupiis.v8i2.5167.

${ }^{19}$ Ibid.Namun, hal yang sangat disayangkan pada masa ini adalah alih-alih pelaksanakan ajaran Pancasila secara murni dan konsekuen, Demokrasi Pancasila yang dikampanyekan oleh Orde Baru hanya sebatas retorika politik belaka. Pada praktik kenegaraan dan pemerintahannya, penguasa Orde Baru bertindak jauh dari prinsip demokrasi. Ketidakemokratisan penguasa Orde Baru ditandai oleh: (1) dominannya peranan militer (ABRI); (2) birokratisasi dan sentralisasi pengambilan keputusan politik; (3) pengebirian peran dan fungsi partai politik; (4) campur tangan pemerintah dalam berbagai urusan partai politik dan publik; (5) politik masa mengambang; (6) monolitisasi ideologi negara; dan (7) inorporasi lembaga non-pemerintah
} 
Pengaturan tentang kekuasaan kehakiman di era orde baru masih terlihat tidak jauh berbeda dengan pengaturan kekuasaan kehakiman di era orde lama. Sebagai contoh dapat dilihat secara organisatoris, admisnistratif, dan finansial yang masing-masing peradilan tersebut masih berada di bawah naungan ekskutif yaitu masing-masing departemen yang menaunginya. Maka indepedensi kekuasaan kehakiman masih belum dapat dilaksanakan, hal ini dapat dilihat pada Pasal 7 ayat (3) Undang-Undang Nomor 14 Tahun 1970 tentang PokokPokok Kekuasaan Kehakiman, yang menentukan bahwa, "masing-masing peradilan tersebut secara organisatoris dan administrative berada di bawah masing-masing departemennya". Sedangkan dalam proses rekruitmen di era orde baru persyaratan untuk menjaadi hakim pada pengadilan tingkat pertama masih mengikuti pola rekrutmen pegawai negeri sipil (PNS). Dalam kedudukannya sebagai pegawai negeri sipil, segala sesuatu yang berkaitan dengan administrasi, organisasi, finansial dan organisasi kehakiman berada di bawah naungan peraturan perundang-undangan yang berlaku bagi pegawai negeri sipil. Maka dari itu, pengisian jabatan hakim sangat tergantung pada kebijakan pemerintah dan penentuan formasi hakim. ${ }^{20}$ Rekruitmen hakim dalam persyaratan, proses serta mekanisme pengadaan hakim tunduk pada Undang-Undang Nomor 8 tahun 1974 tentang Pokok-Pokok Kepegawaian sebelum diubah menjadi Undang-Undang Nomor 43 tahun 1999 tentang Perubahan dari Undang-Undang Nomor 8 tahun 1974 tentang Pokok-Pokok Kepegawaian dengan persyaratan sebagaimana ditentukan melalui Peraturan Pemerintah yang merupakan peraturan pelaksaana dari undang-undang tersebut.

Persyaratan untuk menjadi hakim pengadilan tingkat pertama pada ketiga undang-undang tersebut seluruhnya hampir sama dan harus sebagai pegawai negeri sipil, namun syarat untuk menjadi hakim pada Pengadilan Agama cukup berbeda yakni harus beragama Islam dan berkompetensi sarjana syari'ah atau sarjana hukum yang menguasai hukum Islam. ${ }^{21}$ Persyaratan lainnya untuk menjadi seorang hakim bukan bekas anggota organisasi terlarang Partai Komunis Indonesia, termasuk organisasi massa nya atau bukan seseorang yang terlibat langsung ataupun tak langsung dalam "Gerakan Kontra Revolusi G.30.S/PKI", atau organisasi terlarang yang lain, menurut penulis syarat ini ditetapkan rezim Orde Baru sebagai pemurnian dalam melaksanakan demokrasi pancasila secara "murni". Sehubungan dengan persyaratan untuk menjadi calon hakim pada Pengadilan Tingkat Pertama harus berstatus sebagai Pegawai Negeri Sipil, maka sudah tentu proses dan persyaratan calon hakim serta pola rekruitmen calon hakim dilakukan dengan menggunakan proses dan persyaratan bagi calon Pegawai Negeri Sipil. Maka dari itu, jika seorang calon hakim dinyatakan lulus tes calon hakim dengan status Pegawai Negeri Sipil, maka semua ketentuan yang menyangkut Pegawai Negeri Sipil juga berlaku terhadap hakim, baik pembinaan, penggajian, jenjang karir, sampai dengan pensiun. Apabila calon hakim tersebut tidak lolos dalam seleksi hakim, maka ia dikembalikan dengan status asalnya, yaitu sebagai Pegawai Negeri Sipil dan ditempatkan sesuai dengan kebutuhan.

\section{Rekruitmen Hakim Pengadilan Tingkat Pertama Era Reformasi}

Perubahan yang terjadi pasca amandemen Undang-Undang Dasar 1945 dalam bidang kekuasaan kehakiman selain peraturan perundang-undangan yang terkait, berimplikasi pula pada mekanisme rekrutmen hakim khususnya hakim pada pengadilan tingkat pertama,

\footnotetext{
${ }^{20}$ Firman Floranta Adonara, "Prinsip Kebebasan Hakim Dalam Memutus Perkara Sebagai Amanat Konstitusi Principles Of Fredom Of Justice In Decidene The Case As A Constitutional Mandate," Jurnal Konstitusi 12, no. 1 (2015): 1-20.

${ }^{21}$ Andi Suherman, "Implementasi Independensi Hakim Dalam Pelaksanaan Kekuasaan Kehakiman," SIGn Jurnal Hukum 1, no. 1 (2019): 42-51, https://doi.org/10.37276/sjh.v1i1.29.
} 
tergantung pada peraturan perundang-undangan yang mengaturnya, namun dalam hal teknis rekrutmen hakim pengadilan tingkat pertama masih dalam naungan Mahkamah Agung sebagai lembaga yang menanunginya. ${ }^{22}$

Proses seleksi hakim pada Pengadilan tingkat pertama dilakukan oleh Mahkamah Agung bersama-sama dengan Komisi Yudisial secara transparan, akuntabel, dan partisipatif. Kemudian untuk menindaklanjuti Pasal 14A tersebut Mahkamah Agung dan Komisi Yudisial telah membuat peraturan bersama yaitu Nomor 01/PB/MA/IX/2012 dan 01/PB/P.KY/09/2012 tentang Seleksi Pengangkatan Hakim. Namun peraturan bersama ini telah tidak berlaku lagi dengan keluarnya putusan Mahkamah konstitusi yang menyatakan bahwa proses rekrutmen Pengadilan Tingkat Pertama tidak perlu melibatkan Komisi Yudisial. Maka dengan demikian proses rekrutmen hakim pada Pengadilan Tingkat Pertama dilakukan oleh Mahkamah Agung secara mandiri tanpa melibatkan Komisi Yudisial. Mekanisme rekruitmen calon Hakim pada Pengadilan Tata Usaha Negara (PTUN) pada dasarnya sama dengan rekrutmen calon hakim Pengadilan Umum, yang membedakan hanyalah dasar hukumnya. ${ }^{23}$

Selanjutnya Pengadilan Agama yang merupakan Pengadilan yang dikhususkan bagi umat Islam dalam hal menyelesaikan perkara perkawinan, pewarisan, dan ekonomi Islam. Pengadilan Agama ini dibentuk untuk mengakomodir kepentingan penduduk Indonesia yang mayoritas beragama Islam dan terbesar di dunia. Pada dasarnya proses seleksi hakim Pengadilan Agama dan memiliki pola rekrutmen yang sama dengan Pengadilan Umum dan Pengadilan Tata Usaha Negara. Namun, yang membedakan hanyalah calon hakim Pengadilan Agama harus beragama Islam dan berpendidikan Sarjana Hukum Islam atau Sarjana Hukum yang memahami Syari'at Islam.

Panitia seleksi rekruitmen calon hakim Pengadilan Tingkat Pertama dibentuk oleh Mahkamah Agung menetapkan nama-nama calon hakim. Selanjutnya Mahkamah Agung mengusulkan kepada Presiden nama-nama calon hakim Pengadilan Tingkat Pertama, lalu Presiden mengangkat para hakim pada pada Pengadilan Tingkat Pertama sebagai Hakim sebagaimana diatur dalam Pasal 16 ayat (1) Undang-Undang Nomor 49 Tahun 2009 tentang Pengadilan Umum, yaitu "Hakim Pengadilan diangkat oleh Presiden atas usul Ketua Mahkamah Agung”. Kewenangan dalam hal mengangkat Hakim baik Hakim Tingkat Pertama maupun Tingkat Banding hanyalah Presiden. ${ }^{24}$ Setelah beberapakali perubahan pada UndangUndang di bidang Peradilan sebagaimana yang telah disebutkan di awal, rekrutmen calon hakim dilakukan oleh Mahkamah Agung dan Komisi Yudisial. Keterlibatan Mahkamah Agung dan Komisi Yudisial dalam melakukan seleksi hakim sesuai dengan amanat UndangUndang Nomor 49 Tahun 2009 tentang Perubahan Kedua Atas Undang-Undang Nomor 2 Tahun 1986 tentang Peradilan Umum Pasal 14A ayat (2) bahwa "Proses seleksi pengangkatan hakim Pengadilan Negeri dilakukan bersama oleh Mahkamah Agung dan Komisi Yudisial". Selanjutnya dalam Pasal 14 ayat (3) menentukan bahwa "Ketentuan lebih lanjut mengenai proses seleksi diatur bersama oleh Mahkamah Agung dan Komisi Yudisial". Ketentuan yang sama juga dapat dilihat dalam Pasal 13A ayat (2) dan ayat (3) UndangUndang Nomor 50 Tahun 2009 tentang Perubahan Kedua Atas Undang-Undang Nomor 7 Tahun 1989 tentang Peradilan Agama, dan juga Pasal 14A ayat (2) dan ayat (3) Undang-

\footnotetext{
22 Dachran Busthami, "Kekuasaan Kehakiman Dalam Perspektif Negara Hukum Di Indonesia," Masalah-Masalah Hukum 46, no. 4 (2018): 336, https://doi.org/10.14710/mmh.46.4.2017.336-342.

${ }^{23}$ Muhtadi Muhtadi, "Problematika Yuridis Sistem Alokasi Hukum Dalam Pengawasan Hakim," FIAT JUSTISIA:Jurnal Ilmu Hukum 9, no. 2 (2016): 182-98, https://doi.org/10.25041/fiatjustisia.v9no2.596.

${ }^{24}$ Suparto, "Pemisahan Kekuasaan, Konstitusi Dan Kekuasaan Kehakiman Yang Independen Menurut Islam," Jurnal Selat 4, no. 1 (2016): 115-29.
} 
Undang Nomor 51 Tahun 2009 tentang Perubahan Kedua Undang-Undang Nomor 5 Tahun 1986 tentang Peradilan Tata Usaha Negara.

Pada tahun 2010 untuk pertama kalinya kedua lembaga negara tersebut melakukan rekrutmen hakim pengadilan tingkat pertama. seleksi calon hakim yang melibatkan Mahkamah Agung dan Komisi Yudisial tersebut sesuai dengan amanat masing-masing Undang-Undang Peradilan Agama, Undang-Undang Peradilan Umum, dan Undang-Undang Peradilan Tata Usaha Negara. Namun seiring bergulirnya waktu, kedua Lembaga Negara tersebut berjalan tidak sesuai dengan sebagaimana mestinya, hingga puncaknya adalah dilakukannya uji materi ke Mahkamah Konstitusi oleh Mahkamah Agung terkait ketentuan Pasal 14A ayat (2) dan (3) Undang Nomor 49 Tahun 2009 tentang Perubahan Kedua Atas Undang-Undang Nomor 2 Tahun 1986 tentang Peradilan Umum, Pasal 13A ayat (2) dan (3) Undang-Undang Nomor 50 Tahun 2009 tentang Perubahan Kedua Atas Undang-Undang Nomor 7 Tahun 1989 tentang Peradilan Agama, dan juga Pasal 14A ayat (2) dan ayat (3) Undang-Undang Nomor 51 Tahun 2009 tentang Perubahan Kedua Undang-Undang Nomor 5 Tahun 1986 tentang Peradilan Tata Usaha Negara. Uji materi tersebut diajukan karena ketidakbersediaan Mahkamah Agung terhadap Komisi Yudisial dalam rekrutmen calon hakim hingga akhirnya Mahkamah Konstitusi mengeluarkan Putusan Nomor 43/PUU XIII/2015 tanggal 7 Oktober 2015 yang dalam amar putusannya mengabulkan permohonan pemohon yaitu membatalkan pasal-pasal yang diuji materi. Setelah dikeluarkannya Putusan tersebut yang membatalkan kewenangan Komisi Yudisial dalam ikut terlibat dalam proses rekrutmen calon hakim, selanjutnya Mahkamah Agung menerbitkan Peraturan Mahkamah Agung Nomor 6 Tahun 2016 tentang Penyusunan dan Penetapan Kebutuhan serta Pengadaan Tenaga Hakim yang mulai berlaku mulai 19 Mei 2016. Lalu pada 4 April 2017 kembali menerbitkan Peraturan Mahkamah Agung Nomor 2 Tahun 2017 tentang Pengadaan Hakim yang juga sekaligus mencabut berlakunya Peraturan Mahkamah Agung Nomor 6 Tahun 2016. Menurut Penulis, pada dasarnya esensi dari Peraturan Mahkamah Agung terkait rekrutmen calon hakim yang dilaksanakan pada tahun 2017 dilakukan sendiri oleh Lembaga Negara Mahkamah Agung tanpa andil dari Komisi Yudisial. Pola rekrutmen calon hakim yang dilakukan Mahkamah Agung sendiri bertujuan untuk mewujudkan kekuasaan kehakiman yang mandiri dengan sistem satu atap atau one roof ${ }^{25}$

Peraturan tersebut mengatur tentang tahapan pengadaan hakim yang diawali dengan perencanaan, pengumuman pengadaan hakim, pelamaran, pelaksanaan seleksi, pengumuman hasil seleksi, pengangkatan sebagai CPNS atau calon hakim, pendidikan calon hakim dan pengangkatan sebagai hakim. Atas dikeluarkannya Perma tentang Pengadaan Hakim tersebut yang mekanisme menggunakan pola rekrutmen pegawai negeri sipil, muncul berbagai perdebatan. Sudah semestinya posisi dan kedudukan hakim sebagai pejabat negara dalam hal rekrutmennya diatur melalui undang-undang sebagai bagian dari pengaturan lebih lanjut perihal kekuasaan kehakiman yang tertuang dalam Undang-Undang Dasar 1945. ${ }^{26}$ Selanjutnya adalah Mahkamah Agung yang memposisikan calon hakim sebagai calon pegawai negeri sipil (CPNS) atau pegawai negeri sipil (PNS) sebelum diangkat menjadi hakim, menurut hemat penulis berlebihan serta telah mengurangi wibawa dan kedudukan hakim sebagai Pejabat Negara.

\footnotetext{
${ }^{25}$ Sirajuddin Egalita, "Desain Pengujian Peraturan Perundang-Undangan Secara Integratif Di Bawah Mahkamah Konstitusi," Arena Hukum 11, no. 2 (2018): 388-414, https://doi.org/10.21776/ub.arenahukum.2018.01002.9.

26 Muhammad Habibi, "Independensi Kewenangan Komisi Pemberantasan Korupsi Pasca Perubahan Undang-Undang Nomor 30 Tahun 2002 Tentang Komisi Pemberantasan Korupsi,” Cepalo 4, no. 1 (2020): 38-47, https://doi.org/10.25041/cepalo.v4no1.1962.
} 
Sejatinya, hakim sebagai Pejabat Negara tidak dipandang sebagai CPNS atau PNS meskipun belum diangkat sebagai hakim sekalipun. Akan tetapi, kedudukannya tetap sebagai calon pejabat negara. Hal itu dikarenakan posisi dan kedudukan antara CPNS, PNS dan Pejabat Negara sangatlah jauh berbeda dalam struktur organisasi sistem penyelenggaraan negara dan pemerintahan di Indonesia. Sistem pengadaan hakim tentu sangat berbeda dengan sistem pengadaan CPNS atau PNS pada umumnya. Hakim yang berkedudukan sebagai pejabat negara tidak mungkin disamakan dalam hal rekruitmennya dengan CPNS atau PNS yang selama ini telah sering dilakukan dalam upaya menjaring calon hakim di Indonesia. Pemberian status pejabat negara pada jabatan hakim, didasari pada pemikiran bahwa hakim adalah personil yang menyeleggarakan kekuasaan di bidang yudikatif bukan di bidang eksekutif sehingga status yang melekat pada hakim bukan pegawai negeri sipil. Status sebagai pegawai negeri sipil sangat memungkinkan terjadinya intervensi atas kebebasan hakim (independensi) karena persoalan struktural, psikologis, dan watak korps serta birokrasi yang membawa atau menuntut ikatan tertentu. Kemandirian hakim dalam negara hukum adalah mutlak, hal ini sesuai dengan prinsip "The International Commision of Jurist” yaitu peradilan bebas dan tidak memihak. ${ }^{27}$ Kedepan apabila disahkannya rancangan undang-undang (RUU) jabatan hakim menjadi undang-undang maka pola rekruitmen hakim pengadilan tingkat pertama tidak lagi mengikuti pola rekruitmen pegawai negeri sipil. Dalam beberapa undangundang seperti Undang-Undang Nomor 48 tahun 2009 tentang Kekuasaan Kehakiman dan Undang-Undang Nomor 5 tahun 2014 tentang Aparatur Sipil Negara telah memberikan hakim sebagai jabatan negara. Namun dalam pelaksanaannya status dan kedudukannya masih berpola seperti kedudukan pegawai negeri sipil. Hakim yang sebelumnya merupakan pegawai negeri sipil diubah statusnya menjadi pejabat negara. Hal ini berakibat Hakim tidak lagi masuk ranah eksekutif, baik secara kelembagaan maupun individu. Hakim dan sistem pendukung peradilan diatur secara utuh dan mandiri dalam sistem aparatur yudikatif. Dengan diaturnya sistem satu atap Mahkamah Agung dan Hakim menjadi pejabat negara, independensi kekuasaan kehakiman diharapkan mampu untuk menjalankan fungsi kekuasaan kehakiman yang merdeka untuk menegakkan hukum dan keadilan.

Terakhir, menurut penulis model atau pola rekruitmen hakim Pengadilan Tingkat Pertama yang paling ideal adalah rekruitmen yang dilakukan oleh Mahkamah Agung secara independen karena sebagai lembaga yudisial yang paling tahu akan kebutuhan hakim itu kedepan. Proses rekruitmen hakim tersebut Mahkamah Agung harus mengedepankan aspek kehati-hatian dan tranparansi atau keterbukaan. Dari aspek kehati-hatian Mahkamah Mahkamah agung dapat menilai secara detail seorang calon hakim dari sisi psikologis, pengetahuan, latar belakang, dan lainnya agar dapat menjadi hakim yang independen dalam menegakkan keadilan. Sedangkan dari aspek transparansi atau keterbukaan Mahkamah Agung membuka diri untuk diawasi oleh Komisi Yudisial ataupun lembaga negara lainnya serta masyarakat luas. Juga menginformasikan kepada publik tiap tahapan yang telah dilakukan dalam proses seleksi hakim tersebut agar tindak muncul kembali stigma yang menyatakan terdapat nepotisme ditubuh Mahkamah Agung.

\section{Kesimpulan}

Berdasarkan hasil penelitian dan pembahasan, dapat disimpulkan jika Kekuasaan Kehakiman di Indonesia sejak zaman kemerdekaan telah mengalami pasang surut akibat 
konfigurasi politik yang berkembang di Indonesia sehingga menyebabkan peraturan perundang-undangan di bidang kekuasaan kehakiman banyak mendapat intervensi dari lembaga kekuasaan lainnya sehingga dapat dikatakan hal tersebut membuat terkikisnya independensi hakim. Setelah berakhirnya era Orde Baru yang digantikan dengan era Reformasi dengan Amandemen Undang-Undang Dasar 1945 salah satunya adalah di bidang Kekuasaan Kehakiman yang telah mengalami banyak perubahan. Pada tahun 2010 sesuai dengan amanat masing-masing Undang-Undang Peradilan Agama, Undang-Undang Peradilan Umum, dan Undang-Undang Peradilan Tata Usaha Negara untuk pertama kalinya Mahkamah Agung dan Komisi Yudisial melakukan rekruitmen hakim pengadilan tingkat pertama secara bersama dengan pola rekruitmen yang digunakan masih sama yaitu pegawai negeri sipil.

Pasca putusan Mahkamah Konstitusi Nomor 43/PUU XIII/2015 maka akibat hukum yang ditimbulkan adalah hilangnya kewenangan Komisi Yudisial untuk bersama Mahkamah Agung ikut dalam Proses Seleksi Hakim Pengadilan Tingkat Pertama. Rekrutmen calon hakim pengadilan tingkat pertama yang dilakukan Mahkamah Agung sendiri pun dilakukan pada tahun 2017 masih dengan pola rekruitmen yang sama dengan sebelumnya yaitu Pegawai Negeri Sipil. Padahal sesuai denganUndang-Undang Kekuasaan Kehakiman dan UndangUndang Aparatur Sipil Negara menyatakan dengan tegas bahwa hakim adalah Pejabat Negara. Kedepan rekruitmen hakim Pengadilan Tingkat Pertama yang dilakukan oleh Mahkamah Agung harus menggunakan pola rekruitmen dengan mekanisme seleksi hakim sebagai pejabat negara sehingga terciptanya negarawan yang mengedepankan independensi hakim dalam mencari keadilan tanpa intervensi pihak manapun. Saran dalam penelitian ini adalah rekruitmen hakim yang dilakukan mandiri oleh Mahkamah Agung menggunakan mekanisme seleksi Pejabat Negara pada hakim Pengadilan Tingkat Pertama dengan mengedepankan asas kehati-hatian dan keterbukaan (transparansi). Sehingga dalam prosesnya Mahkamah Agung membuka diri untuk terus diawasi oleh Komisi Yudisial, lembaga negara lainnya, serta masyarakat luas. Segera disahkannya rancangan undang-undang jabatan hakim menjadi undang-undang yang merefleksikan kemandirian kekuasaan kehakiman yang menjadikan kedudukan hakim sebagai pejabat negara. Sehingga tidak ada lagi dikotomi antara hakim sebagai pegawai negeri sipil dan hakim sebagai pejabat negara.

\section{Daftar Pustaka}

A. Buku

Asshidiqie, Jimly, 2006,Implikasi Perubahan UUD 1945 Terhadap Pembangunan Hukum Nasional,Jakarta: Mahkamah Konstitusi.

Asshidiqie, Jimly, 2009, Pengantar Ilmu Hukum Tata Negara, Jakarta: Sinar Grafika.

Asshidiqie, Jimly, 2011, Konstitusi dan Konstitusionalisme Indonesia, Jakarta: Sinar Grafika.

Asshidiqie, Jimly, 2012, Perkembangan dan Konsolidasi Lembaga Negara Pasca Reformasi, Jakarta: Sinar Grafika.

Kadier, Adies, 2018, Menyelamatkan Wakil Tuhan (Memperkuat Peran dan Kedudukan Hakim), Jakarta: Merdeka Book.

Komisi Yudisial, 2017, Problematika Hakim dalam Ranah Hukum, Pengadilan dan Masyarakat di Indonesia: Studi Sosio-Legal, Jakarta: Pusat Analisis dan Informasi Komisi Yudisial.

Marzuki, Peter Mahmud, 2010,Penelitian Hukum,Jakarta: Kencana.

Palguna,I Gede Dewa, 2013, Pengaduan Konstitusional, Jakarta: Sinar Grafika. 
Soekanto,Soerjono dan Sri Mamudji, 2012, Penelitian Hukum Normatif: Suatu Tinjauan Singkat (cetakan ke-14),Jakarta: Rajawali Pers.

Syahuri, Taufiqurrohman, 2011,Tafsir Konstitusi Berbagai Aspek, Jakarta: Kencana Prenada Media Group.

Syahuri, Taufiqurrohman, 2013,Pembaharuan Sistem Hakim Sebagai Pondasi Mewujudkan Peradilan Bersih (makalah), Jakarta: Komisi Yudisial.

B. Jurnal

Adonara, Firman Floranta. "Prinsip Kebebasan Hakim Dalam Memutus Perkara Sebagai Amanat Konstitusi Principles Of Fredom Of Justice In Decidene The Case As A Constitutional Mandate." Jurnal Konstitusi 12, no. 1, 2015: 1-20.

Bustamin, Bustamin, and Rony Jaya. "Urgensi Checks And Balances Ketatanegaraan Indonesia Dan Islam." JURIS (Jurnal Ilmiah Syariah) 18, no. 2, 2019: 221-32. https://doi.org/10.31958/juris.v18i2.1740.

Busthami, Dachran. "Kekuasaan Kehakiman Dalam Perspektif Negara Hukum Di Indonesia." Masalah-Masalah Hukum 46, no. 4, 2018: 336. https://doi.org/10.14710/mmh.46.4.2017.336-342.

Dramanda, W. "Menggagas Penerapan Judicial Restraint Di Mahkamah Konstitusi." Jurnal Konstitusi 11, no. 4, 2014: 617-31.

Egalita, Sirajuddin. "Desain Pengujian Peraturan Perundang-Undangan Secara Integratif Di Bawah Mahkamah Konstitusi." Arena Hukum 11, no. 2, 2018: 388-414. https://doi.org/10.21776/ub.arenahukum.2018.01002.9.

Habibi, Muhammad. "Independensi Kewenangan Komisi Pemberantasan Korupsi Pasca Perubahan Undang-Undang Nomor 30 Tahun 2002 Tentang Komisi Pemberantasan Korupsi." Cepalo 4, no. 1, 2020: 38-47. https://doi.org/10.25041/cepalo.v4no1.1962.

Likadja, Jeffry Alexander Ch. 'Memaknai 'Hukum Negara (Law Through State)' Dalam Bingkai 'Negara Hukum (Rechtstaat)."' Hasanuddin Law Review 1, no. 1, 2015: 75-86.

Muhtadi, Muhtadi. "Problematika Yuridis Sistem Alokasi Hukum Dalam Pengawasan Hakim." FIAT JUSTISIA:Jurnal Ilmu Hukum 9, no. 2, 2016: 182-98. https://doi.org/10.25041/fiatjustisia.v9no2.596.

Muslih, M. "Negara Rukum Indonesia Dalam Perspektif Teori Hukum Gustav Radbruch (Tiga Nilai Dasar Hukum)." Legalitas Edisi Juni 2013 4, no. 1, 2013: 142.

Nasution, Aulia Rosa. "Urgensi Pendidikan Kewarganegaraan Sebagai Pendidikan Karakter Bangsa Indonesia Melalui Demokrasi, HAM Dan Masyarakat Madani." JUPIIS: JURNAL PENDIDIKAN ILMU-ILMU SOSIAL 8, no. 2, 2016: 201-12. https://doi.org/10.24114/jupiis.v8i2.5167.

Ridlwan, Zulkarnain. "Negara Hukum Indonesia Kebalikan Nachtwachterstaat." FIAT JUSTISIA:Jurnal Ilmu Hukum 5, no. 2, 2014: 141-52. https://doi.org/10.25041/fiatjustisia.v5no2.56.

Sihaloho, Meylin. "Seleksi Pengangkatan Hakim Dalam Sistem Peradilan Indonesia: Kajian Putusan Mahkamah Konstitusi Nomor 43/Puu-Xii/2015." Jurnal Wawasan Yuridika 33, no. 2, 2016: 204-18. https://doi.org/10.25072/jwy.v33i2.103.

Suherman, Andi. "Implementasi Independensi Hakim Dalam Pelaksanaan Kekuasaan Kehakiman." SIGn Jurnal Hukum 1, no. 1, 2019: 42-51. https://doi.org/10.37276/sjh.v1i1.29.

Suparto. "Pemisahan Kekuasaan, Konstitusi Dan Kekuasaan Kehakiman Yang Independen Menurut Islam." Jurnal Selat 4, no. 1, 2016: 115-29.

Sutiyoso, Bambang. "Mencari Format Ideal." Jurnal Hukum IUS QUIA IUSTUM 17, no. 2, 2010: 217. http://www.sunan-ampel.ac.id/publicactivity/. 